Journal of Management

Vol. XX No. X, Month XXXX 1-26

DOI: $10.1177 / 0149206315626270$

(C) The Author(s) 2016

Reprints and permissions:

sagepub.com/journalsPermissions.nav

\title{
Linking Merger and Acquisition Strategies to Postmerger Integration: A Configurational Perspective of Human Resource Management
}

\author{
Nir N. Brueller \\ University of Haifa \\ Abraham Carmeli \\ Tel Aviv University \\ Gideon D. Markman \\ Colorado State University
}

The extant literature tends to frame mergers and acquisitions (M\&As) and postmerger integration (PMI) as strategies and outcomes, but this framing often leaves their underlying processes underexplored. We address this gap by redirecting attention to the view that M\&As are largely embedded in social and human practices. Our conceptual study identifies three generic $M \& A$ strategies - annex \& assimilate, harvest \& protect, and link \& promote - and matches them with three well-known PMI outcomes (i.e., absorption, preservation, and symbiosis, respectively). Using a configurational perspective and drawing upon the ability-motivation-opportunity (AMO) model, we develop a conceptual framework that reveals why and how AMO-enhancing human resource management (HRM) practices can link M\&A strategies and PMI outcomes. Finally, we elaborate on the theoretical and practical contributions and chart a course for future inquiry and research applications for the M\&A-HRM-PMI triad and its processes.

Keywords: merger and acquisition; postmerger integration; strategic human resource management; M\&A-PMI relations; ability-, motivation-, and opportunity-enhancing HRM practices

\footnotetext{
Acknowledgments: We wish to thank the editor and anonymous reviewers for their helpful and constructive feedback, as well as Esther Singer for her editorial comments on earlier drafts of this paper. We acknowledge the financial support of the Eli Hurvitz Institute of Strategic Management at Tel Aviv University. The authors are listed in alphabetical order.
}

Corresponding author: Nir N. Brueller, Faculty of Management, University of Haifa, 119 Abba Khoushy Ave., Haifa 31805, Israel.

Email:nbrueller@univ.haifa.ac.il 
Figure 1

A Broad Conceptual Model of Merger and Acquisition-Postmerger Integration-Human Resource Management Relationships

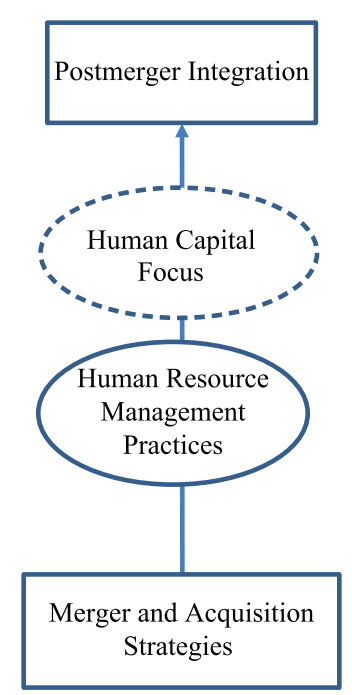

Firms use mergers and acquisitions (M\&As) to accelerate their growth, seize and expand on valuable capabilities, access assets (e.g., human capital) that are costly to imitate, and even reduce competition - yet most M\&A strategies fail to meet their objectives (Haleblian, Devers, McNamara, Carpenter, \& Davison, 2009). Acknowledging diverse factors that may contribute to such failure (e.g., financial miscalculations, capability misalignment, and crosscultural mismatches), many studies and meta-analyses attribute the poor performance of M\&As to the intricate postmerger integration (PMI) phase (Datta, Pinches, \& Narayanan, 1992; King, Dalton, Daily, \& Covin, 2004). Indeed, the difficult-to-realize synergies and destroyed value are among the reasons why M\&A scholars are coupling their macrofocused studies with microprocesses related to PMI (cf. Galpin \& Herndon, 2014; Hitt, Harrison, Ireland, \& Best, 1998; Larsson \& Finkelstein, 1999).

Research on PMI aims to explain the nature of acquirer-acquired relations as a means to develop a normative theory that would guide future M\&A scholarship and PMI practices (Birkinshaw, Bresman, \& Håkanson, 2000; Haspeslagh \& Jemison, 1991). Acknowledging that workplace and personnel issues present a core challenge in M\&A-PMI contexts (e.g., Aguilera \& Dencker, 2004; Chang, Gong, \& Peng, 2012), we take a human resource management (HRM) perspective to further develop this area of research. Synthesizing research in management, finance, and economics, we offer a normative framework to explain why and how HRM practices can configure M\&A strategies into PMI outcomes (see Fig. 1 for an overview of our conceptual model). Thus, our research question concerns why and how HRM practices that focus on personnel can help translate M\&A strategies into more effective PMIs at the firm level.

Using an HRM perspective, our thesis aims to make two main contributions to the M\&A and PMI literatures. First, HRM is a foundational human capital mechanism for executing 
diverse tasks and strategies. As an organizational infrastructure, HRM harnesses employees' engagement to perform their jobs, manage resources, and fulfill firm-level objectives. HRM practices are instrumental in addressing diverse workplace issues (e.g., recruiting, performance assessment, job design and rotation, layoffs, and restructuring, to name a few). We therefore theorize that an organizational infrastructure that aims to compound and extend human effort is pivotal in M\&A-PMI relations. Second, because an HRM perspective provides a fine-grained context that infuses microlevel processes into macrolevel theoretical lenses, it should help clarify and explain how firms can match or configure their M\&A-PMI relations.

Building on the ability-motivation-opportunity (AMO) model (Appelbaum, Bailey, Berg, \& Kalleberg, 2000; Blumberg \& Pringle, 1982; Chang et al., 2012), we explain how HRM practices mediate the M\&A-PMI relations. We also elaborate on the reasons behind this phenomenon and show how each M\&A-HRM-PMI path takes on different functions, follows distinct logics, and yields specific interdependencies between acquiring and acquired firms. Interestingly, this configurational approach also clarifies why even well-crafted M\&A strategies and well-intended PMIs are unlikely to fully meet their objectives, unless they are matched — or configured - by suitable AMO-enhancing HRM practices.

To the best of our knowledge, this is a first attempt to clarify why and how HRM practices mediate the relations between M\&A strategies and PMI outcomes. Indeed, past studies tended to frame acquisitions as events (e.g., the increased use of event-study methodologies), but the introduction of an HRM lens stresses that M\&A-PMI relations are better viewed as processes through which HRM practices play a critical role — starting with due diligence during the predeal stages through the transition phases that bring M\&A strategies into PMI outcomes.

\section{Background Research: M\&As, PMI, and HRM}

Research on the M\&A-PMI interface and HRM studies are rather vast, and despite their scope and diversity, they have evolved with relatively limited overlap. To establish a baseline, we start by synthesizing the M\&As, PMI, and HRM literatures into a reasonably condensed review (for a full overview see some excellent articles, such as Haleblian et al., 2009; Shi, Sun, \& Prescott, 2012; Wright \& Boswell, 2002). We then offer a conceptual elaboration on why and how variations in HRM practices (i.e., those that leverage on AMO-enhancing processes) mediate the relationship between M\&A strategies and PMI outcomes. For clarity and ease, Table 1 summarizes key constructs and offers examples.

\section{M\&A Strategies}

Despite numerous studies, it is difficult to classify M\&A strategies into distinct types because M\&As are diverse, have different aims, and thus often call for context-specific considerations, processes, and capabilities. Earlier studies classify M\&As on the basis of industry designation, appearance, and objectives, and recent work adopts a more dichotomizing view (e.g., horizontal vs. vertical, friendly vs. hostile, related vs. unrelated, domestic vs. global, and even structural-e.g., "platform" vs. "bolt-on" acquisitions; Chatterjee \& Brueller, 2015; Haleblian et al., 2009). Such classifications have certainly improved our understanding of M\&As but do not sufficiently clarify the nature of disruption imposed upon 
Table 1

\section{Merger and Acquisition-Postmerger Integration-Human Resource Management Relationships: Construct Labels, Functions, Definitions, and Examples}

\begin{tabular}{|c|c|c|c|}
\hline $\begin{array}{c}\text { Merger and } \\
\text { Acquisition Strategies }\end{array}$ & Annex \& Assimilate & Harvest \& Protect & Link \& Promote \\
\hline $\begin{array}{l}\text { Merger and acquisition } \\
\text { goals }\end{array}$ & $\begin{array}{l}\text { Absorbing assets } \\
\text { (primarily tangible) from } \\
\text { targets }\end{array}$ & $\begin{array}{l}\text { Capturing and preserving } \\
\text { intangible assets } \\
\text { (e.g., capabilities, } \\
\text { partnerships) from } \\
\text { targets }\end{array}$ & $\begin{array}{l}\text { Linking self-interest to shared } \\
\text { interest by cocreating } \\
\text { boundary-spanning } \\
\text { opportunities for both firms } \\
\text { as they operate independently }\end{array}$ \\
\hline $\begin{array}{l}\text { Strategic and } \\
\text { operational } \\
\text { leadership held by } \\
\ldots\end{array}$ & Acquirer & $\begin{array}{l}\text { Target holds some } \\
\text { strategic and } \\
\text { operational power, but } \\
\text { acquirer sets the tone }\end{array}$ & $\begin{array}{l}\text { Both targets and acquirers hold } \\
\text { ample strategic power and } \\
\text { operational leadership }\end{array}$ \\
\hline PMI Outcomes & Absorption & Preservation & Symbiosis \\
\hline Examples & $\begin{array}{l}\text { The merger of United-- } \\
\text { Continental Airlines }\end{array}$ & $\begin{array}{l}\text { Cisco's acquisition of } \\
\text { IronPort and Linksys }\end{array}$ & EMC's acquisition of VMware \\
\hline $\begin{array}{l}\text { Autonomy of acquired } \\
\text { target }\end{array}$ & None (target is dissolved) & $\begin{array}{l}\text { Moderate and usually } \\
\text { operational and tactical }\end{array}$ & High and strategic \\
\hline Relationship power & $\begin{array}{l}\text { Asymmetrical: All power } \\
\text { held by acquirer }\end{array}$ & $\begin{array}{l}\text { Moderate: Most power } \\
\text { held by acquirer }\end{array}$ & Symmetrical and synergistic \\
\hline $\begin{array}{l}\text { Interfirm trust } \\
\text { Human Resource }\end{array}$ & Minimal & Moderate & High \\
\hline $\begin{array}{c}\text { Management } \\
\text { Practices }\end{array}$ & Ability & Ability \& Motivation & $\begin{array}{c}\text { Ability, Motivation, \& } \\
\text { Opportunity }\end{array}$ \\
\hline Examples & $\begin{array}{l}\text { Recruitment, selection, } \\
\text { training }\end{array}$ & $\begin{array}{l}\text { As in left cell, plus: } \\
\text { Performance and } \\
\text { development } \\
\text { programs, competitive } \\
\text { pay systems, upward } \\
\text { career mobility }\end{array}$ & $\begin{array}{l}\text { As in left cells, plus: } \\
\text { Flexible job designs, cross- } \\
\text { firm engagement programs, } \\
\text { transparent management }\end{array}$ \\
\hline $\begin{array}{l}\text { Practices designed } \\
\text { to } \ldots\end{array}$ & $\begin{array}{l}\text { Enhance personnel skills } \\
\text { and abilities of personnel }\end{array}$ & $\begin{array}{l}\text { As in left cell, plus: } \\
\text { Enhance motivation of } \\
\text { personnel }\end{array}$ & $\begin{array}{l}\text { As in left cells, plus: } \\
\text { Empower employee to engage at } \\
\text { higher levels across both firms }\end{array}$ \\
\hline Human capital focus & $\begin{array}{l}\text { Removal of redundancies } \\
\text { and integration of human } \\
\text { capital }\end{array}$ & $\begin{array}{l}\text { As in left cell, plus: } \\
\text { Personnel retention and } \\
\text { capability alignment }\end{array}$ & $\begin{array}{l}\text { As in left cells, plus: } \\
\text { Reciprocal empowerment and } \\
\text { cause-based programs that } \\
\text { transcend firm boundaries }\end{array}$ \\
\hline
\end{tabular}

acquisition parties, nor do they elaborate on the changes M\&As impress on processes, operation, and HRM practices.

Following more nascent work, we deviate from a dichotomous view and group M\&A strategies into three main types - annex \& assimilate, harvest \& protect, and link \& promote acquisitions - chiefly on the basis of operational complexity, implications for PMI, and HRM needs (Brueller, Carmeli, \& Drori, 2014; Galpin \& Herndon, 2014; Haleblian et al., 2009; Koller, Goedhart, \& Wessels, 2010). We describe each of the three M\&A strategies in more detail and offer examples shortly. As a preview, the annex $\&$ assimilate acquisitions focus on absorbing targets' assets, the harvest \& protect acquisitions aim to capture and integrate capabilities, and the link \& promote acquisitions seek to cocreate boundary-spanning, interfirm synergistic ties. 
Annex \& assimilate $M \& A s$. These acquisitions consume a target firm in its entirety or reap core assets while dissolving redundant units, dated assets, and/or unneeded personnel (Brueller et al., 2014). Acquirers aim to consolidate market power by annexing and digesting targets' core assets, and when merging parties are of equal size, their integration increases in complexity (Chakravarthy \& Lorange, 2007). When acquirers are exceptionally large and targets are relatively small, both integration and digestion are reasonably simple, swift, and fairly undisruptive. For instance, the global Danish cleaning company, Integrated Service Solutions, has grown mostly by acquiring small local cleaning firms and quickly assimilating them (Horovitz, 2004). Integrated Service Solutions does not change itself substantively but instead applies and enforces its own strategic planning, financial controls, culture, and HRM systems throughout its absorbed targets (Chakravarthy \& Lorange). When acquirers and targets are large, even if their business models are quite similar - as is often seen in commodity industries, such as steel or oil and gas - the homogenization process is appreciably more complex (e.g., BP's merger with Arco and Amoco, Exxon with Mobil, and Chevron with Texaco).

Under the "mergers of equals" scenario-especially where parties are quite sizable, have a wide customer interface, and seek to combine most of their assets - complexity can quickly become even more daunting. Consider, for instance, the 2010 merger of United and Continental Airlines, which required the integration of two global networks, eight major hubs, and 5,500 daily flights serving nearly 400 destinations. This complexity explains why 5 years later, United continued to grapple with myriad integration problems, including hobbled operations, angry passengers, and soured relations with employees. Another example is the $\$ 30$ billion merger between Ciba-Geigy and Sandoz that created pharmaceutical company Novartis. The combined firm opted to craft new strategies, processes, and capabilities rather than adhere to those of either of its predecessors. The new strategy focused on life sciences (i.e., nutrition, pharmaceuticals, and agriproducts), while the $\$ 7$ billion Ciba Specialty Chemicals business was spun off in 1997. The new processes included structuring R\&D by therapeutics (rather than geographic area) and shifting the firm's compensation policy from a system based on seniority to one based on performance across all departments and managerial levels. These new capabilities entailed the creation of Novartis' oncology franchise (cf. Koller et al., 2010).

Thus annex \& assimilate acquisitions - especially the mergers of equals - are monumental undertakings, with far-reaching and long-lingering operational complexities. The process of homogenizing two firms (or more) into one often necessitates the development of new strategies, retooled operations, restructured systems, and reorganized business models (Brueller et al., 2014; Zott, Amit, \& Massa, 2011).

Harvest \& protect $M \& A s$. Acquirers use such M\&As to seize new capabilities, processes, and key personnel in order to expand their product offerings, enhance asset utilization, leverage on talent (e.g., improve R\&D performance), and gain access to new markets (Puranam, Singh, \& Chaudhuri, 2009). For example, such acquisitions give firms flexibility to reallocate personnel to more productive tasks across functions to fulfill new strategic direction (Swaminathan, Groening, Mittal, \& Thomaz, 2014). In these cases, preserving acquired capabilities - which are often embedded in personnel - takes precedence over efforts to gain scale advantage. Firms seeking these M\&As can pursue either small or large targets. Small targets are often startups with capabilities critical for product or technology extension, but 
their growth is hindered by insufficient capital infrastructure, scale expertise, or managerial know-how (Brueller, Segev, Ellis, \& Carmeli, 2015; King, Slotegraaf, \& Kesner, 2008). For example, small biotech companies typically lack the sales channels, marketing budget, and ties with physicians, patients, and regulators needed to bring their products to markets (Markman \& Waldron, 2014). Larger firms often acquire smaller ventures for their innovation capabilities, which would be more expensive or too slow to develop internally (Puranam et al.).

Because harvest \& protect acquisitions focus on seizing, preserving, and realizing capabilities, which are often embedded in personnel, we later explain why these acquisitions require distinctly more specialized and involved HRM practices (and different human capital focus) than those needed for the annex \& assimilate M\&As.

Link \& promote $M \& A s$. These M\&As are particularly unique because rather than focusing on acquiring assets or capabilities, the primary aim is to cocreate boundary-spanning and interfirm shared value creation that accelerate the growth and strength of both acquiring and acquired firms (Chakravarthy \& Lorange, 2007). Also, instead of grafting capabilities of a target firm or force-fitting R\&D units onto an acquirer's asset base, the link \& promote acquisitions aim to accelerate interfirm learning and renewal. It is a regenerative, relational effort where both firms coleverage complementary assets, capabilities, and know-how (Haleblian et al., 2009; Kanter, 2009). Thus, these acquisitions require discipline and foresight to ensure that targets remain operationally and strategically autonomous, independent, and self-sufficient. Indeed, the alignment of resources between two parties with complementary competencies is a major operational challenge, but when executed well, it can bring synergistic gains to both parties (Capron, Dussauge, \& Mitchell, 1998; King et al., 2008).

When link \& promote acquirers protect and promote their targets' autonomy, both parties improve knowledge exchange, mutual learning, innovation, and cross-operational agility (Haleblian et al., 2009; Karim \& Mitchell, 2000). For example, EMC's \$635 million acquisition of VMware, a computer-server software pioneer, allowed EMC to modularize two functions - storage and server virtualization-that were previously incompatible. This loose postacquisition governance resembles an alliance or a federation and was viewed by VMware's CEO as an optimal management structure (Butler, 2015). Naturally, the concepts of complementarity, boundary spanning, and synergy are not new (Aldrich \& Herker, 1977), but their execution - particularly in M\&A-PMI contexts - remains a challenge. As we show below, however, it can be alleviated by suitable HRM practices.

To recap, annex \& assimilate M\&As focus on absorbing targets' assets and dissolving redundancies, while harvest $\&$ protect acquisitions seek to capture and preserve targets' capabilities - especially unique processes and key personnel. Link \& promote M\&As are distinct, as the cogeneration of interfirm ties, regenerative learning, and synergies among business units means that parties seek shared value creation by maintaining operational autonomy while working synchronously on boundary-spanning projects and objectives.

\section{$P M I$}

Recognizing that M\&As often trigger substantial restructuring, research that traditionally asked outcome-focused questions, such as "Which acquisition strategy is likely to succeed?" (Chatterjee, 1986; Chatterjee \& Lubatkin, 1990; Lubatkin, 1983, 1987; Porter, 1987; Seth, 1990), began to shift toward process-related questions, such as "What processes and internal 
infrastructures might facilitate capability transfer, cross-firm learning, new value creation, and synergistic gains?" (Haspeslagh \& Jemison, 1991; Larsson \& Finkelstein, 1999; Pablo, 1994). The conceptualization of PMI as M\&A-derived outcomes stimulated diverse studies (e.g., Cording, Christman, \& King, 2008; Haleblian et al., 2009; Zollo \& Singh, 2004), many of which build on Haspeslagh and Jemison's popular framework.

Extending earlier studies, Haspeslagh and Jemison (1991) argued that PMIs are marked by two dimensions: acquirer-target interdependence and target's autonomy. Then, by plotting the two dimensions into a two-by-two matrix, they identified four main PMI outcomes: absorption, preservation, symbiosis, and holding (Galpin \& Herndon, 2014). PMI absorption is most suitable when interdependence is high and a target's assets are insensitive to complete digestion. Acquirers should seek the PMI preservation when interdependence is low but a target autonomy is critical (e.g., to preserve capabilities) and seek PMI symbiosis when both interdependence and target's autonomy are high. The PMI holding entails no integration per se, and it accounts for less than $10 \%$ of all deals. Therefore, following other M\&A studies, we henceforth focus on the first three PMIs: absorption, preservation, and symbiosis (cf. Brueller et al., 2014; Ellis, 2004; Nahavandi \& Malekzadeh, 1988; Schweiger, 2002).

An important takeaway from PMI research is its conceptual evolution. Initially, PMIs were underdefined, but Haspeslagh and Jemison's (1991) introduction of the acquirer-target interdependence and target's autonomy dimensions allowed scholars to define PMIs with greater precision. Indeed, the integration processes associated with absorption, preservation, and symbiosis differ quite profoundly.

\section{HRM and Human Capital}

Going beyond administrative tasks, such as labor relations, payroll, and compliance, HRM focuses on diverse issues pertaining to workforce management (Lepak \& Snell, 2002), and we suggest that discussion of personnel and HRM should coincide with strategic choices. Indeed, abundant research corroborates that HRM can improve organizational processes and effectiveness (e.g., B. E. Becker \& Gerhart, 1996; Combs, Liu, Hall, \& Ketchen, 2006; Huselid, 1995; Kehoe \& Wright, 2013; Wright, Dunford, \& Snell, 2001; Wright, Gardner, Moynihan, \& Allen, 2005). Furthermore, years of scholarly effort to unpack various employment architectures have led to the development of several HRM taxonomies depicting how organizations convert human capital into organizational outcomes (cf. Delaney \& Huselid, 1996; Guest, 1997; Huselid; Ichniowski, Shaw, \& Prennushi, 1997; Jackson, Schuler, \& Jiang, 2014; Lepak \& Snell).

This rich literature is summarized in numerous review articles (cf. B. E. Becker \& Huselid, 1998; Delery \& Shaw, 2001; Jiang, Takeuchi, \& Lepak, 2013). To remain within reasonable bounds, we briefly elaborate on one area of HRM research that is especially germane to the M\&A-PMI interface-namely, the AMO (ability-motivation-opportunity) model. As recapped by Jiang, Lepak, Hu, and Baer's (2012) meta-analysis based on 116 articles (featuring 120 samples representing a total of 31,463 organizations), ability- or skill-enhancing HRM practices include selection and hiring (Ahmad \& Schroeder, 2003), training (Akhtar, Ding, \& Ge, 2008; Appleyard \& Brown, 2001; Armstrong, Flood, Guthrie, Liu, Mac-Gurtain, \& Mkamwa, 2010), staffing and recruiting (Bartrajn, Stanton, Leggat, Gasimir, \& Fraser, 2007; Batt, Colvin, \& Keefe, 2002), and development practices (Collins \& Smith, 2006). Motivation-enhancing HRM practices focus primarily on personnel 
retention and capability alignment through the aid of compensation systems (Bartrajn et al.; Batt \& Colvin, 2011), career-enhancing practices (Beltran-Martin, Roca-Puig, Escrig-Tena, \& Bou-Llusar, 2008), and performance and development programs (Yang \& Lin, 2009). And finally, opportunity-enhancing HRM practices form opportunity-spawning contexts and infrastructures through commitment, empowerment, and cause-based programs where personnel can further develop and accelerate organizational learning. Such practices might entail decentralized structures and information-sharing protocols (Katou \& Budhwar, 2006); empowerment, engagement, and networking programs (Cabello-Medina, Lopez-Cabrales, \& Valle-Cabrera, 2011); grievance and voice mechanisms (Delaney \& Huselid, 1996); and rotational assignments, to name a few.

Evidence shows that AMO-enhancing HRM practices improve diverse firm-level outcomes, such as processes, operations, and financial performance (cf. Appelbaum et al., 2000; Bailey, Berg, \& Sandy, 2001; Batt \& Colvin, 2011; Batt et al., 2002; Boxall \& Purcell, 2008; Delery \& Shaw, 2001; Gardner, Wright, \& Moynihan, 2011; Gerhart, 2007; Huselid, 1995; Jiang et al., 2012; Katz, Kochan, \& Weber, 1985; Kehoe \& Wright, 2013; Lepak, Liao, Chung, \& Harden, 2006; Liao, Toya, Lepak, \& Hong, 2009; Subramony, 2009). Our assessment of this scholarship is that AMO-enhancing HRM practices are a strong organizational modality to address the economic, social, and operational complexities that M\&As demand and PMIs create.

Increasingly, several HRM studies focus on human capital-for example, personnel knowledge, skills, ability, creativity, intelligence, judgment, and wisdom that produce individual and/or organizational value (cf. B. E. Becker \& Gerhart, 1996; Carmeli \& Schaubroeck, 2005; Nyberg \& Wright, 2015; Wright, Coff, \& Moliterno, 2014). We view human capital as a means to convert personnel-level capacity and effort into organizational-level outcomes. For example, boundary-spanning effort and firm wealth creation are increased when different human capital types are combined and matched by or configured with cospecialized organizational resources and capabilities (Mahoney \& Kor, 2015). Building on such scholarship and the view that microprocesses and macro-outcomes create opportunities to address mesolevel processes (Cappelli \& Scherer, 1991; Nyberg \& Wright), we theorize that understanding human capital at the individual level - and matching and configuring those with organizational capabilities - can shed light on firm-level processes and outcomes. Specifically, we blend micro- and macroviews and evince that HRM practices that tap into and leverage on human capital can catapult M\&A strategies into PMI outcomes (Nyberg, Moliterno, Hale, \& Lepak, 2014; Ployhart, Nyberg, Reilly, \& Maltarich, 2014).

Having introduced (albeit briefly) the main parts of our conceptual model, the next section elaborates on and integrates these points into a more detailed conceptual framework (see Figure 2). To recall, our thesis is that each distinct M\&A-PMI path is mediated by suitable HRM practices. Figure 2 offers a configuration view that depicts how firms leverage their HRM practices to align their M\&A strategies with suitable PMIs (Fiss, 2007).

\section{Conceptual Development}

We should reemphasize that even the best-crafted M\&A strategies and well-achieved PMIs are rather disruptive and tend to produce substantial uncertainty, identity issues, and stress that affect employees, suppliers, buyers, and even rivals. To clarify, M\&A strategies and their 


\section{Figure 2}

\section{A Conceptual Model of Merger and Acquisition Strategies and Goals, Human Resource Management Practices, Human Capital Focus, and Postmerger Integrations}

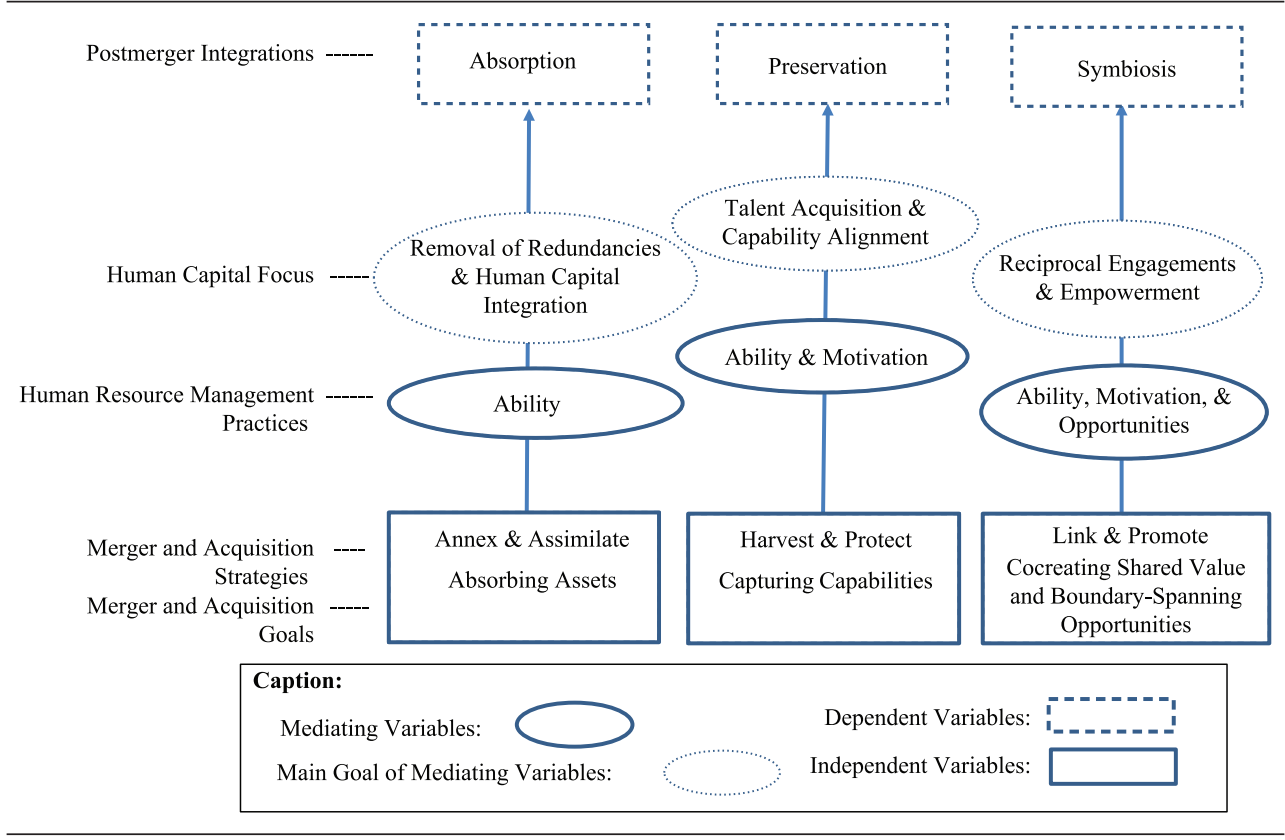

PMIs represent unusual threat-provoking contexts where personnel in both acquiring and acquired firms experience daunting pressure and concerns about processes, consequences, and employability. Indeed, before employees become excited about combined market share or synergistic gains, they worry about personal consequences, such as job security, potential cuts in pay or benefits, chain of command, or possible relocation, to name a few.

While loss of job and income are a most salient threat, research shows that other riskseven if they do not materialize — can be highly demoralizing as well. Examples include negative changes in incentive systems (Citera \& Rentsch, 1993); undesirable transfers and relocations, as well as changes in job responsibilities (Buunk \& Janssen, 1992; Hubbard \& Purcell, 2001); and loss of opportunity, such as derailed career path (Larsson \& Finkelstein, 1999). As employees consider the threat, disruption, and consequences of such changes, they compare their situation to that of referent others - a natural reaction that often exacerbates a sense of dissociation and hopelessness especially when they perceive themselves to be worse off compared with others who were affected by the same merger. This leads to an even stronger sense of hopelessness, rejection, demoralization, and even betrayal (Tyler, Boeckmann, Smith, \& Huo, 1997).

The complicated nature of M\&A-PMI relations is not new. However, raising awareness about the stress and anxiety they often induce - for instance, by noting how M\&As can disrupt labor relations and introduce new attraction-selection-attrition contexts (Chatman, 1991; Ployhart, Weekley, \& Baughman, 2006; Schneider, 1987) — can clarify and justify the 
decision to explore the M\&A-PMI relations through the mediating lenses of HRM practices, which is the next topic.

\section{Annex \& Assimilate-Ability-Enhancing HRM-PMI Absorption}

As noted, annex \& assimilate acquisitions aim to seize mostly tangible assets (e.g., real estate, production facilities, intellectual property, and technology) while dissolving or selling unneeded resources, including excess personnel. Under these M\&As, acquired firms cease to exist but acquirers frequently engage some of their personnel in order to better integrate and utilize their tangible assets. Naturally, the absorption of personnel is a delicate and timeconsuming process requiring HRM managers to determine - often under time pressure and budgetary constraints - which employees to retain, and how to integrate them, and which ones to dismiss. Among the factors often considered are surplus or redundant corporate functions involving management, marketing, information technology, legal, and, yes, even human resource (HR) personnel. Moreover, acquirers rarely engage HRM executives in premerger planning, which is a serious oversight given that most annex \& assimilate M\&As and PMI absorption entail substantial downsizing (Siegel \& Simons, 2007).

It is important to recognize, therefore, that ability-focused HRM practices entail a careful screening of personnel in order to identify and retain those essential to asset integration while decisively letting go of the rest. As further clarified below, ability-focused HRM practices play a critical role in mediating the relationships between annex $\&$ assimilate acquisitions and PMI absorption. Understanding that prescreening and early selection of personnel determine, to a large extent, the outcome of an acquisition sheds doubt on the common (and crude) view that acquirers are merely applying indiscriminate cost-containment measures (Haleblian et al., 2009; Schuler \& Jackson, 2003). Our thesis, however, proposes that ability-focused HRM practices are management tools that must be engaged early, during the due diligence process prior to the merger, in order to carefully identify and select the skill sets needed to lower the disruption and cost and to maximize the speed and efficacy of integration.

Many M\&A studies and firms underestimate the critical role played by ability-focused HRM in identifying, extracting, and retaining the right skills from acquired firms while removing redundancies, curbing overcapacities, consolidating incongruent practices, and eliminating excess assets (Galpin \& Herndon, 2014). Returning to an earlier example, the United-Continental merger eliminated not only redundant routs and hub services but also 600 front-office jobs and many back-office functions. Certainly, workforce morale is important, especially during massive layoffs. Yet in the context of annex \& assimilate strategies and PMI absorption, the focus is on removing duplicate functions, addressing operational integrations, and meeting payroll needs and contractual obligations. And because redundancies increase costs, acquirers depend heavily on applying ability-focused HRM practices, such as sorting for fit and mining the able from the less essential personnel.

According to the AMO model, ability-enhancing HRM practices allow acquirers to recruit and select employees (from each firm) who have the right skills and attitude needed to complete a merger (Delaney \& Huselid, 1996). Relatedly, HRM practices such as retraining programs, selective hiring, and skill-enhancing training help to win the hearts and minds of capable personnel from acquired firms. All of these practices are critical to improving morale and raising and integrating the collective human capital base of acquirers (e.g., CabelloMedina et al., 2011; Takeuchi, Lepak, Wang, \& Takeuchi, 2007; Yang \& Lin, 2009; Youndt 
\& Snell, 2004). Teva Pharmaceutical Industries CEO Vigodman (2015) noted that they refined their capability for screening and retaining only the most suitable employees and teams from their targets.

Over and above removing redundancies on the basis of skills, ability-enhancing HRM practices are useful for selecting a transition team; setting up integration timelines; communicating rules, routines, and expectations; enforcing processes and milestones; and balancing operational trade-offs while managing the integration of absorbed personnel. Similarly instrumental in dissolving a target's autonomy is the role of ability-focused HRM in identifying and preventing areas of friction and harmonizing cross-cultural issues, often by attracting, retaining, and deploying the right personnel (while pruning others; Dhanaraj, Lyles, Steensma, \& Tihanyi, 2004). On the basis of this logic, we suggest the following proposition:

Proposition 1: Ability-enhancing HRM practices mediate the relationship between annex \& assimilate strategies and PMI absorption.

\section{Harvest \& Protect-Ability- and Motivation-Enhancing HRM-PMI Preservation}

Harvest \& protect acquisitions intend to harness and preserve the capabilities, partnerships, and other intangible assets of target firms. For instance, to preserve the capabilities and vital partnerships of IronPort (a maker of products and services that protect enterprises against Internet threats), Cisco enabled IronPort to operate almost as it did prior to the acquisition. IronPort was grafted into Cisco's security business unit by using a PMI preservation (Yirrell, 2007). It comes as no surprise that harvest \& protect acquisitions and PMI preservation are best paired with HRM practices aiming to safeguard and keep targets' capabilities intact so they can then be redeployed by acquirers. Considering the critical role played by ability-enhancing HRM practices in removing redundancies and preserving human capital, we suggest that when parties complement their ability-enhancing HRM effort with motivation-enhancing HRM practices, they can greatly strengthen personnel's buy-in and, thus, enable the harvest $\&$ protect acquisitions and their PMI preservation. There are several reasons for this prediction.

First, while ability-enhancing HRM practices ensure that personnel possess appropriate human capital skills, motivation-enhancing HRM practices tend to strengthen the association between the work, intentions, effort, and even identity of employees with their rewards, retention, and commitment. Practices such as performance and career development plans, competitive pay and benefits, flexible work design, and job security tend to motivate employees to engage at a higher level (Ryan \& Deci, 2000). An important nuance to stress at this point is that even when training improves individual skills and ability, these benefits are more likely to produce firm-level outcomes when coupled with motivation-enhancing HRM practices. This blending of practices tends to expand the abilities, skills, and motivation of employees (Tharenou, Saks, \& Moore, 2007). And, of course, as engagement increases among personnel, so does their resilience against disruptions, including those stemming from acrimonious M\&As. For instance, studies show that ability- and motivationenhancing HRM practices are associated with increased engagement levels and reduced voluntary turnover (Batt et al., 2002; Gardner et al., 2011; Guthrie, 2001; Huselid, 1995; Sun, Aryee, \& Law, 2007). 
Second, extant research shows that the combination of ability- and motivation-enhancing HRM practices contributes greatly to a firm's operational and financial performance (cf. Chuang \& Liao, 2010; Collins \& Smith, 2006; Gelade \& Ivery, 2003; Gong, Law, Ghang, \& Xin, 2009; McClean \& Collins, 2011; Sun et al., 2007). As Figure 2 indicates, harvest \& protect acquisitions and PMI preservation aim to capture the capabilities of target firms to facilitate their appropriation by the acquirer. However, research shows that many capabilities are not quite amenable to being suddenly uprooted from their original context and simply implanted in an acquirer's business (Dhanaraj et al., 2004). Such grafting may exacerbate the erosion of capabilities that are embedded in personnel, some of whom may passively resent their acquirers while others simply quit. Following Chadwick, Super, and Kwon (2015), we suggest that firms are more likely to preserve human capital, causally ambiguous practices, and poorly codified protocols - thus facilitating the preservation of PMI - when they rely on HRM practices aimed at enhancing both ability and motivation.

This logic is further supported by studies showing that the combination of ability- and motivation-enhancing HRM practices allows firms to develop positive attitudes (as measured by job satisfaction, commitment, and perceived organizational support) and improve organizational citizenship behavior (Campbell, McCloy, Oppler, \& Sager, 1993; Jiang et al., 2012). Our view is that such combination is critical to the development of a productive work relationship between acquiring and acquired firms and preserving the know-how, capabilities, and processes of target firms. Because talent often represents the lion's share of an acquisition's value and potential, ability- and motivation-enhancing HRM practices are also a useful modality to mitigate personnel turnover (Collins \& Smith, 2006). HRM practices that preserve job contexts also alleviate the stress and anxiety often experienced by employees during M\&As in a phenomenon known as "merger syndrome" (Marks, 1997; Marks \& Mirvis, 1998).

Consider the case of Johnson \& Johnson. Rather than combine a harvest \& protect strategy with PMI preservation, it annexed and then absorbed Cordis Corporation into its angioplasty business, thereby squandering valuable capabilities that were costly to replace and losing key personnel, know-how, and uncodified processes (cf. Finkelstein, 2003). As noted, capabilities often reside within the social and professional fabric of a target's personnel. Particularly in knowledge-intensive acquisitions, the expertise and potential of key personnel are often more valuable (ex post) than the technology and intellectual property they have developed in the past (Bower, 2001; Granstrand \& Sjölander, 1990; Mayer \& Kenney, 2004). Research shows that knowledge rooted in employees and human capital can allow acquirers to improve upon diverse time-consuming processes (Dierickx \& Cool, 1989; Leonard-Barton, 1995; Puranam \& Srikanth, 2007). Because ability- and motivation-enhancing HRM entice key personnel to stay on board and engage, such practices are critical for enhancing the association between harvest \& protect acquisitions and PMI preservation (Birdi et al., 2008).

A final point is that, when compared with annex \& assimilate and their PMI absorption, harvest $\&$ protect acquisitions and their PMI preservation require appreciably more interpersonal dialogue and interfirm coordination, especially about priorities, how and where a target's capabilities might complement or conflict with the acquirer's processes, and how human capital is captured and when and where it should be redeployed. For example, acquirers might grant a target's CEO veto power regarding personnel layoffs, a practice that Cisco formalized with some of its acquisitions (Paulson, 2001). At the interpersonal level, Cisco 
implemented a mentorship program that matches acquirer-target peers to facilitate socialization, educate new employees, provide access to vital information, and learn about the culture at Cisco (Jonsson \& Foss, 2011; Paulson). A similar practice was implemented by Banc One where "new affiliates were matched with 'sister' or 'mentor' banks" (Uyterhoeven, 1996: 7).

Whereas the issue of human capital retention in annex \& assimilate and PMI absorption often applies to a relatively smaller subset of the target's employees, in harvest \& protect acquisitions and PMI preservation, a significantly larger part of a target's value and potential resides in the broader ecosystem or social network and interpersonal relationships. In such cases, the importance of acquired human capital lies not only in what personnel know but also whom they know and work with, including buyers, suppliers, and regulators who are external to their firms (Galpin \& Herndon, 2014). Acquirers interested in complementarities must not only identify the location of a target's capabilities but also preserve the human capital, social milieu, and professional ties that nurture and sustain such capabilities (Bower, 2001; Huber, 1991; Puranam, 2001). Hence:

Proposition 2: Ability- and motivation-enhancing HRM practices mediate the relationships between harvest $\&$ protect strategies and PMI preservation.

\section{Link \& Promote-Ability-, Motivation-, and Opportunity-Enhancing HRM- PMI Symbiosis}

A primary objective of link \& promote acquisitions is to accelerate the boundary spanning, growth, and strength of both acquiring and acquired firms through opportunities for cross-firm learning, knowledge flow, and renewal (Chakravarthy \& Lorange, 2007). As noted in Table 1 and shown in Figure 2, we reason that this M\&A strategy is best coupled with PMI symbiosis because of the overlapping focus on strengthening ties between firms to infuse greater strategic and operational agility to both parties (Ranft \& Lord, 2000). We also suggest that the combination of ability-, motivation-, and opportunity-enhancing HRM practices (AMO) - with human capital focus on reciprocal engagement and empowerment-will positively mediate the associations between link \& promote acquisitions and PMI symbiosis. We draw upon studies that underscore this theoretical reasoning. To clarify, opportunityenhancing HRM practices are those designed to empower and inspire personnel to build on their knowledge, skills, and ability — as well as their ambitions - to advance interfirm objectives, processes, and outcomes. Examples include flexible job design, personnel engagement programs, and transparent management (Jiang et al., 2012).

The complementary effects of AMO-enhancing HRM practices are impressive because despite occurring at the individual, human capital level, they eventually augment and amplify organization-level outcomes. Skill- and motivation-building HRM practices inspire personnel to develop new competencies that, in turn, broaden their career and promotion opportunities inside and outside their organizations (Tharenou et al., 2007). Opportunity-enhancing HRM practices (e.g., coaching, high-potential career tracks, succession plans, job rotations, exchange programs) enhance employees' human capital as well as their identification with wider-reaching organizational objectives while elevating their commitment to pursue more challenging goals and to engage at a higher level (Ryan \& Deci, 2000). To better appreciate how HRM practices at the individual level contribute to outcomes at the firm level, consider 
how a $1 S D$ increase in AMO-enhancing HRM practices is associated with, respectively, a $0.13,0.18$, or $0.09 S D$ increase in firms' financial performance (Jiang et al., 2012).

Naturally, AMO-enhancing HRM practices are complementary, and some might argue that acquirers should always maximize all three HRM dimensions (ability, motivation, and opportunity) in every M\&A event. In theory, such advice is applicable to many firm-level functions (not only HRM) and even individual-level action, but reality and scholarly work show that all seemingly positive relations reach inflection points after which the relations turn asymptotic and often negative, leading to a pattern of curvilinear relations (e.g., the "toomuch-of-a-good-thing" effect; cf. Pierce \& Aguinis, 2013). In addition, the development, maintenance, and deployment of well-rounded AMO-enhancing HRM practices entail significant costs as well as legal and operational complexities. Diverging from traditional thinking - where more AMO-enhancing HRM practices are better and the three (ability, motivation, and opportunity) are inseparable - we stress that different strategic objectives, operational needs, and budgetary constraints call on firms to emphasize different combinations of AMOenhancing HRM practices. In fact, viewing employees as constantly exerting their full abilities, motivation, and opportunities to each task-regardless of budgetary constraints and operational needs - is not only unrealistic but counterproductive too.

Our suggestion that different M\&A contexts guide firms on which AMO-enhancing HRM practices to use and when is consistent with a configurational perspective; sometimes it is ideal to employ a single component, while other situations call for a combination of two or even all three. For instance, ability-enhancing HRM practices aid in removing redundancies and increasing compliance, but such objectives are hardly pivotal in link \& promote acquisitions and PMI symbiosis. The blending of ability- and motivation-enhancing HRM practices helps to preserve capabilities, but in link \& promote acquisitions and PMI symbiosis, capabilities are preserved because parties remain autonomous. Still, the combination and complementarity of all three AMO dimensions is the most suitable modality in PMI symbiosis, as such HRM practices promote boundary-spanning interfirm citizenship behavior, trust, reciprocal engagements, professional and social ties, learning, empowerment, and synergy (Appelbaum et al., 2000; Jiang et al., 2012).

Interestingly, the AMO-enhancing HRM practices are not limited to human capital attributes such as reciprocal engagements and empowerment; they are also associated with elevated well-being, positive attitude, higher engagement levels, and superior performance among employees (e.g., Hempel, Zhang, \& Han, 2012; Wagner, 1994). Of course, all of these attributes are foundational for PMI symbiosis. Compared with only one or two dimensions of HRM, the combination of all three gives employees more opportunities, facilitates creativity and problem solving, and promotes opportunities to engage stakeholders outside their firm. A strong fusion of the AMO-enhancing HRM practices also calls for greater transparency and openness, autonomy and trust, collaboration and meritocracy, and a general sense that one's job entails a greater purpose (Chuang, Jackson, \& Jiang, in press). Again, all of these qualities are critical for buttressing the association between link \& promote strategies and PMI symbiosis.

Research also reveals that all three HRM dimensions (ability, motivation, and opportunity) are related to diverse organizational-level outcomes. Notable among these are opportunities and greater motivation among employees to develop new knowledge, skills, and ability (G. S. Becker, 1975; Carmeli \& Schaubroeck, 2005) and stronger professional ties (Gant, 
Ichniowski, \& Shaw, 2002) as well as to engage in shared value creation and cross-organizational citizenship behaviors (Appelbaum et al., 2000; Collins \& Smith, 2006). AMOenhancing HRM practices are conducive to high-quality interactions that encourage even new hires and temporary employees to engage across firm boundaries and, thus, to perform their job better (Gittell, Seidner, \& Wimbush, 2010; Vogus, 2006). We reason that by facilitating interfirm relations that promote mutuality, empowerment, and trust, AMO-enhancing HRM practices augment the relationship between link \& promote strategies and PMI symbiosis.

In sum, link \& promote acquisitions require personnel who hold different organizational identities to suddenly work together and forge new professional and social ties. AMOenhancing HRM practices are a main modality to create the necessary human capital, professional ties, social fabric, and organizational context to manage newly formed interdependencies that are called upon to facilitate PMI symbiosis (Smith, Amiot, Smith, Callan, \& Terry, 2013). Hence:

Proposition 3: AMO-enhancing HRM practices mediate the relationships between link \& promote strategies and PMI symbiosis.

\section{Discussion}

Firms pursue M\&A strategies for a variety of weighty reasons - for example, to secure new assets, customers, and capabilities; reduce costs and competition; and increase growth and synergies, to name a few. To illustrate how critical these objectives are, the value of worldwide M\&As in 2014 alone totaled \$3.5 trillion; M\&A deals are a "big deal" for firms, managers, and scholars. Despite their hopeful objectives and worldwide valuation, most M\&As and their associated PMIs are highly disruptive-M\&As are galvanized with process mismatches and cross-operational difficulties that often lead to performance decline. Indeed, M\&A-PMI relations often exacerbate tension across business units and personnel, and they are rampant with defection by talent, customers, and even suppliers. These observations, combined with historical accounts that between $70 \%$ and $90 \%$ of M\&As fail to realize their objectives (Christensen, Alton, Rising, \& Waldeck, 2011; Galpin \& Herndon, 2014) plus their ultimate dependence on human engagement, persuaded us to study M\&A-PMI relations from an HRM perspective.

At a broad level, our HRM-focused framework infuses microlevel concepts and especially processes (the AMO framework and attention to human capital issues) into macrolevel theoretical lenses to explain how firms can configure their M\&A-PMI relations. That is, M\&A research is often dominated by macroperspectives, but this paper adds a microview and applies a configurational approach to examine how and why AMO-enhancing HRM practices mediate the relationship between M\&A strategies and PMI outcomes. Our premise is that although M\&A-PMI relations vary considerably, acquiring and acquired firms can reduce the disruption and risk by carefully configuring themselves and applying distinct HRM practices.

This paper offers several contributions to the literature. First, even prior to the melding of the HRM practices and the AMO model with the M\&A-PMI literature, our framework stands to advance research in this area by clarifying why M\&A strategies must be matched by 
suitable PMIs. Indeed, we speculate that the M\&A-PMI configuration is a robust conceptual platform that can address diverse contingencies regardless of variations in industry, business cycle, scale, complexity, risks and obstacles, or even the type of transaction. Specifically, and being a configurational framework, it clarifies that annex \& assimilate acquisitions employ PMI absorption, harvest \& protect acquisitions call for PMI preservation, and link \& promote acquisitions are best matched by PMI symbiosis. Articulating the different M\&A-PMI configurations is important because each pair is based on a different strategic objective and distinct PMI outcome, follows distinct logics, and exhibits specific acquirer-acquired interdependencies.

A second and probably key contribution of this study is the configuration of an HRM perspective based on the AMO model. While the operational, legal, and especially the crosscultural difficulties that M\&As pose are well known, the fact that most employees are quite removed from, yet often find themselves on the receiving end of, M\&A choices management made for them, has not been adequately addressed. Given that employees are rarely asked to be "sold" or "bought," it is surprising that their role, from passive resistance and open backlash to active support and full stewardship, are rarely addressed explicitly in M\&A-PMI studies. We reasoned that because AMO-enhancing HRM practices are human capital building systems, they can effectively mediate the M\&A-PMI relations - for example, by harnessing personnel's human capital to engage and execute M\&A strategies and bring about effective PMI.

Complementing our M\&A-PMI configurations with the AMO model, the normative framework (see Fig. 2) features three main paths: First, as Proposition 1 states, abilityenhancing HRM practices (such as removing redundancies and preserving assets) mediate the relationship between annex \& assimilate strategies and PMI absorption. Second, and consistent with Proposition 2, ability- and motivation-enhancing HRM practices (e.g., removing redundancies while simultaneously preserving human capital to conserve capabilities) mediate the relationships between harvest $\&$ protect acquisitions and PMI preservation. Finally, in accordance with Proposition 3, AMO-enhancing HRM practices (e.g., causebased programs that transcend firm boundaries, e.g., that promote reciprocity, empowerment, and cross-organizational citizenship behavior) mediate the relationships between link \& promote strategies and PMI symbiosis.

Consistent with research on dynamic capabilities (Eisenhardt \& Martin, 2000; Teece, Pisano, \& Shuen, 1997) and HR flexibility (Way, Fay, Wright, Snell, Chang, \& Gong, 2015), our framework encourages acquirers to carefully assess their HRM capabilities before they consider, let alone approve, any M\&A-PMI combination. For example, acquirers whose HRM capabilities are limited to ability-enhancing practices should avoid link \& promote acquisitions and PMI symbioses, even if their would-be targets are highly lucrative. Similarly, acquirers whose HRM practices are restricted to enhancing opportunity should not try to pursue annex \& assimilate acquisitions and PMI absorption. This perspective clarifies why even well-crafted M\&A strategies are unlikely to fully meet their objectives unless they are carefully matched by suitable PMIs and configured (or mediated) by the correct HRM practices (and human capital).

The M\&A-HRM-PMI framework advanced here recognizes different degrees of integration across a wide range of strategic objectives. It clarifies, for instance, why acquiring and acquired firms must view their M\&A-HRM-PMI configuration from multiple perspectives 
and, more critically, engage their HRM functions early - during the premerger due diligence phase. Indeed, we worry that the secretive nature of the due diligence processes preceding most M\&As leaves many HR departments in the dark, engaging them only once a public announcement has been made. This is too late to issue effective warnings or apply changes concerning HRM-related risks and liabilities. Some of our own work reveals that when HR executives are involved in the premerger due diligence phase, acquirers routinely uncover such deal breakers as pension liabilities, union issues, defined contribution plans, executive contracts, and retiree medical plans, to name a few. In other words, well-engaged HRM functions can scout and avert bad deals and help firms to prioritize integration activities and influence PMI outcomes.

We also explained why the M\&A-HRM-PMI configuration is a more complete model. Historically, M\&A-PMI value was projected from a legal point of view and a financial due diligence perspective, but we stress that precisely because M\&As are highly complex and disruptive, economic value can become more realizable with early and ongoing HRM engagement. Rather than using HRM as a supporting, compliance, or post hoc tool-merely implementing strategic decisions that have already been made-M\&A-related choices, including financial, legal, and personnel, must be made in conjunction. Just as chief financial officers enable M\&As by conducting financial due diligence and allocating financial resources, HR executives should run human capital reviews and match HRs and talent with firm needs. For example, when seeking to acquire the Hungarian firm Biogal, Teva Pharmaceutical Industries' diligence revealed that 50\% of Biogal's 2,000 employees were redundant. In light of the expected effects of massive layoffs on the small town of Debrecen, Teva conditioned further negotiations towards a deal on Biogal's agreeing to the layoffs. Failing to reach an agreement, negotiations broke off and were resumed only 5 years later, when Biogal finally accepted Teva's plan for restructuring, which allowed Biogal to reach the efficiency level prevailing across Teva's factories. Only then could Teva finalize the deal and commit resources for "early retirement, social welfare, retraining, a placement agency, relocation, and financial aid for ex-employees who would be interested in establishing a small business venture" (Almor, Tarba, \& Benjamini, 2009: 44-45).

Our conceptual framework unearths some counterintuitive relations rarely acknowledged in extant literature. Scholars recognize the distinct nature of each of the AMO-enhancing HRM practices, but most studies highlight their complementary nature and assume that more is better (i.e., the view that firms should always aim to enhance all three dimensions: ability, motivation, and opportunity). We, too, recognize the utility and complementary nature of the AMO-enhancing practices, which is precisely what Proposition 3 advocates. Also, should an acquirer possess all three AMO-enhancing capabilities without concern for cost or complexity, they may certainly apply all three across diverse M\&A-PMI contexts. However, HRM practices can quickly overrun cost estimates, and their overdeployment can cause considerable friction and waste. Hence, we question whether a more-is-better approach truly aligns with organizational reality and conclude that, given the high price tag of most M\&As and budget-constrained HR departments, overdeployment of HRM practices would indeed be unwarranted.

The notion of "too much of a good thing" is a challenging theoretical issue deserving more attention, but here we stress another view: that the application of all AMO-enhancing HRM practices irrespective of M\&A-PMI relations is not only expensive but may even 
undermine deals. Consider, for example, the Teva Pharmaceutical Industries' acquisition of Pharmachemie, which commanded a $40 \%$ share of the Dutch market. Because of its strong local reputation, the acquired firm insisted on remaining autonomous. In other words, preserving "the company as an independent entity was a supreme value" (Tarba, Almor, \& Benjamini, 2012: 93). This contrasted with the fact that Pharmachemie's capabilities were not up to par. Pharmachemie had two costly plants that were inefficient by Teva's standards and development/marketing functions that Teva would eventually disband. Hoping to please Pharmachemie by showing sensitivity, Teva deviated from the M\&A-HRM-PMI configuration initially called for in the deal (i.e., annex \& assimilate acquisitions; ability-enhancing HRM practices; and PMI absorption) and instead pursued PMI symbiosis. Teva offered considerable AMO-enhancing HRM practices, but Pharmachemie was too weak and misconfigured to succeed on its own in Teva's global context. As Wil Van Maris, Pharmachemie's HR manager acknowledged: "We were the most dynamic company in the Netherlands, yet we are the least in Teva" (Claus, 2006: 898). After squandering valuable resources and time, both parties recognized their misconfigured M\&A-HRM-PMI triage, and Teva fully absorbed Pharmachemie. This example demonstrates that deploying the best AMO-enhancing HRM practices to the wrong M\&A-PMI path can be quite wasteful; again, acquirers need to configure their HRM practices to the correct M\&A-PMI context they face.

We do not elaborate on contexts in which acquirers underinvest in AMO-enhancing HRM practices as extant research is quite clear that such underinvestment has devastating ramifications, including increased disengagement and reduced quality (Tsui, Pearce, Porter, \& Tripoli, 1997; Wang, He, \& Mahoney, 2009). For instance, underinvestment in HRM practices weakens the psychological bond between employees and their firms, so it is easy to see how it can undermine M\&A-PMI relations. In fact, investment in and attention to HRM practices is one of the main motivations for this conceptual study: that extant research underestimates the critical (mediating) role that HRM practices play in M\&A-PMI relations.

We hardly discussed organizational culture, so as a litmus test of the framework utility and generalizability, it may be interesting to see whether it can shed light on the role that culture plays in M\&A-PMI relations. To clarify, when M\&As fall short of achieving their financial objectives, studies often attribute the failure to a clash of cultures between the combined entities (Galpin \& Herndon, 2014). In fact, in a recent report, cultural conflict was the cause of $30 \%$ of failed M\&As (Miller \& Fernandes, 2009). Scholars describe this phenomenon as cultural misfit (Weber \& Camerer, 2003), acculturation and acculturative stress (Larsson \& Lubatkin, 2001), and social construction of cultural differences (Vaara, Sarala, Stahl, \& Björkman, 2012). These perspectives contribute greatly to the consensus that culture plays a critical role in M\&A outcomes. However, what remain rather unclear are the conditions under which culture clash might or might not undermine M\&A-PMI relations. Indeed, some acquirers seem to manage and execute their M\&As despite significant cultural differences (Stahl \& Voigt, 2008; Viegas-Pires, 2013).

How can our conceptual framework shed light on this issue? Moving from left to right in Figure 2, our framework suggests that a culture clash's strongest disruptive potential is likely with PMI absorption, where acquiring and acquired firms are fully and completely integrated into a single operational entity. An example of this is the Daimler and Chrysler merger, where discordant cultures included diverging operating styles, levels of formality, and philosophy on a gamut of issues ranging from pay and expenses to strategy and operations. With PMI 
preservation, the threat of a culture clash is reduced, mostly because acquiring firms do not seek to digest entire targets but instead to "surgically" harvest only a subset of a target's capabilities and personnel. Naturally, as the number of capabilities and personnel that acquirers seek to graft into their operation or business units grows, the greater the threat and disruption that culture clash may pose. Finally, because under PMI symbioses both acquiring and acquired firms remain highly autonomous and independent, these PMIs are more resilient to cultural differences. Of course, an acute size disparity (in which acquirers are especially large and targets are particularly small) is a general shock absorber that mitigates the influence of cultural differences and renders them less likely to derail M\&A-PMI relations (Markman \& Waldron, 2014). Critically, the greater the disruption that culture clashes impose on M\&APMI relations, the stronger the configurational role that HRM practices must play in matching and harmonizing culture and value systems.

In sum, acquirers often know how to track and manage the financial and operational aspects of M\&As, but harmonizing divergent cultures is quite daunting. Cultures are difficult to measure and manage directly, and, sadly, few organizations exercise the same rigor and discipline in assessing, steering, and overseeing cultural integration that they apply to operational synergy. These observations suggest that because (1) HR departments are often responsible for personnel and culture and (2) failure to address personnel issues and harmonize culture mismatch is a key reason for some of the derailed M\&A-PMI relations, HRM has an enormous opportunity to clarify M\&A-PMI relations and even drive up their success rate. The notion that expected "synergies" and accretive "value" depend on the management of people and cultures is not new - and assertions such as "culture eats strategy for lunch" are quite popular (Coffman \& Sorensen, 2013) — but explaining why, when, and where an HRM perspective and the AMO model can help firms deal with these issues constitutes an important contribution. As noted, to better quantify the soft risks, acquirers must engage HRM functions in premerger assessments and due diligence phases. Who knows more about people and culture than HRM?

\section{Future Research}

Broadly, our message is that in the context of M\&A-PMI relations, HRM is a management system that is both highly underutilized in practice and understudied in scholarly research. For example, some M\&A studies - perhaps because of a focus on the mergers at the expense of the acquisitions - give the impression that most acquired firms are fully absorbed into acquiring firms. Seeking to bring a more balanced view, we stressed that PMIs exist along a wide continuum, ranging from full absorption to partial preservation to, lastly, optimized symbiosis. Yet for conceptual clarity, we trichotomized this continuum into three main PMI outcomes: absorption, preservation, and symbiosis. Hence, one venue for future research is to recognize this continuum more explicitly and bring greater clarity, perhaps by exploring other M\&A types or dimensions and PMI outcomes along this continuum. A related avenue for future research concerns the relational context in which acquirers and targets implement nonstructural coordination mechanisms. While Puranam and colleagues (2009) studied the important role of common ground and knowledge, we argue that these constructs do not capture "the reluctance of some recipients to accept knowledge from the outside (e.g., the 'not invented here' or NIH syndrome)" (Szulanski, 1996: 31). We suggest that concepts such 
as relationship capacity should receive more attention as they may play an important role in enabling the development of trust underlying harvest \& protect and link \& promote acquisitions.

M\&A strategies and their PMI consequences are formulated and measured on the macrolevel, but we stressed that their implementations through AMO-enhancing HRM practices are often executed on the microlevel. We hope that future scholarship in this area will explore other, perhaps more nuanced, modalities by which HRM practices mediate certain M\&A-PMI relations. Similarly, it is essential to explore how firms and their managers determine the amount of AMOenhancing HRM practices devoted to each M\&A-PMI combination. Acquirers can engage in certain M\&A-HRM-PMI combinations, which is similar to what has been cultivated in the literature on ambidexterity where choices span spatial separation, temporal differentiation, and "semistructures" (Eisenhardt, Furr, \& Bingham, 2010). This is important for shifting the discussion from describing M\&A-PMI as events to explaining the processes by which each M\&AHRM-PMI path is pursued so we can better understand how firms create PMI absorption, preservation, and symbiosis. Addressing such issues is crucial, as scholars strive to unravel processes that underpin M\&A strategies and enrich our theorizing about PMI outcomes.

\section{Conclusion}

Seeking to bring greater clarity to M\&A-PMI relations, we identified three main M\&A strategies: annex \& assimilate, harvest \& protect, and link \& promote. We then matched these strategies with three core PMI outcomes: respectively, absorption, preservation, and symbiosis. Finally, we developed a configurational framework (see Fig. 2) to explain why and how AMO-enhancing HRM practices mediate the relationship between M\&A strategies and PMI outcomes. We hope that this effort will open up new opportunities for research and theory on the various M\&A-HRM-PMI paths.

\section{References}

Aguilera, R. V., \& Dencker, J. C. 2004. The role of human resource management in cross-border mergers and acquisitions. The International Journal of Human Resource Management, 15: 1355-1370.

Ahmad, S., \& Schroeder, R. G. 2003. The impact of human resource management practices on operational performance: Recognizing country and industry differences. Journal of Operations Management, 21: 19-43.

Akhtar, S., Ding, D. Z., \& Ge, G. L. 2008. Strategic HRM practices and their impact on company performance in Chinese enterprises. Human Resource Management, 47: 15-32.

Aldrich, H., \& Herker, D. 1977. Boundary spanning roles and organization structure. Academy of Management Review, 2: 217-230.

Almor, T., Tarba, S. Y., \& Benjamini, H. 2009. Unmasking integration challenges: The case of Biogal's acquisition by Teva Pharmaceutical Industries. International Studies of Management and Organization, 39(3): 32-52.

Appelbaum, E., Bailey, T., Berg, P., \& Kalleberg, A. L. 2000. Manufacturing advantage: Why high-performance work systems pay off. Ithaca, NY: ILR Press.

Appleyard, M. M., \& Brown, G. 2001. Employment practices and semiconductor manufacturing performance. Industrial Relations, 40: 436-471.

Armstrong, G., Flood, P. C., Guthrie, J. P., Liu, W., Mac-Gurtain, S., \& Mkamwa, T. 2010. Beyond high performance work systems: The impact of including diversity and equality management on firm performance. Human Resource Management, 49: 977-998.

Bailey, T., Berg, P., \& Sandy, G. 2001. The effect of high performance work practices on employee earnings in the steel, apparel, and medical electronics and imaging industries. Industrial \& Labor Relations Review, 54: 525-543. 
Bartrajn, T., Stanton, P., Leggat, S., Gasimir, G., \& Fraser, B. 2007. Lost in translation: Exploring the link between HRM and performance in healthcare. Human Resource Management Journal, 17: 21-41.

Batt, R., \& Colvin, A. J. S. 2011. An employment systems approach to turnover: Human resources practices, quits, dismissals, and performance. Academy of Management Journal, 54: 695-717.

Batt, R., Colvin, A. J. S., \& Keefe, J. 2002. Employee voice, human resource practices, and quit rates: Evidence from the telecommunications industry. Industrial \& Labor Relations Review, 55: 573-594.

Becker, B. E., \& Gerhart, B. 1996. The impact of human resource management on organizational performance: Progress and prospects. Academy of Management Journal, 39: 779-801.

Becker, B. E., \& Huselid, M. A. 1998. High performance work systems and firm performance: A synthesis of research and managerial implications. In G. R. Ferris (Ed.), Research in personnel and human resources management: 53-101. Greenwich, CT: JAI Press.

Becker, G. S. 1975. Human capital. New York: Columbia University Press.

Beltran-Martin, I., Roca-Puig, V., Escrig-Tena, A., \& Bou-Llusar, J. 2008. Human resource flexibility as a mediating variable between high performance work systems and performance. Journal of Management, 34: 10091044.

Birdi, K., Clegg, C., Patterson, M., Robinson, A., Stride, C. B., Wall, T. D., \& Wood, S. J. 2008. The impact of human resource and operational management practices on company productivity: A longitudinal study. Personnel Psychology, 61: 467-501.

Birkinshaw, J., Bresman, H., \& Håkanson, L. 2000. Managing the post-acquisition integration process: How the human integration and task integration processes interact to foster value creation. Journal of Management Studies, 37: 395-425.

Blumberg, M., \& Pringle, G. 1982. The missing opportunity in organizational research: Some implications for a theory of work performance. Academy of Management Review, 7: 560-569.

Bower, J. L. 2001. Not all M\&As are alike_-and that matters. Harvard Business Review, 79(3): 92-101.

Boxall, P., \& Purcell, J. 2008. Strategy and human resource management. Basingstoke, England: Palgrave Macmillan.

Brueller, N. N., Carmeli, A., \& Drori, I. 2014. How do different types of mergers and acquisitions facilitate strategic agility? California Management Review, 56(3): 39-57.

Brueller, N. N., Segev, A., Ellis, S., \& Carmeli, A. 2015. Knowing when to acquire: The case of multinational technology firms. International Business Review, 24: 1-10.

Butler, B. 2015. VMware CEO Gelsinger still committed to EMC Federation. Network World, August 31. http://www. networkworld.com/article/2977551/virtualization/vmware-ceo-gelsinger-still-committed-to-emc-federation. html. Accessed November 6, 2015.

Buunk, B., \& Janssen, P. 1992. Relative deprivation, career issues, and mental health among men in midlife. Journal of Vocational Behavior, 40: 338-350.

Cabello-Medina, C., Lopez-Cabrales, A., \& Valle-Cabrera, R. 2011. Leveraging the innovative performance of human capital through HRM and social capital in Spanish firms. The International Journal of Human Resource Management, 22: 807-828.

Campbell, J. P., McCloy, R. A., Oppler, S. H., \& Sager, C. E. 1993. A theory of performance. In N. Schmitt \& W. C. Borman (Eds.), Personnel selection in organizations: 35-70. San Francisco: Jossey-Bass.

Cappelli, P., \& Scherer, P. D. 1991. Missing role of context in OB: The need for a meso-level approach. Research in Organizational Behavior, 13: 55-110.

Capron, L., Dussauge, P., \& Mitchell, W. 1998. Resource redeployment following horizontal acquisitions in Europe and North America, 1988-92. Strategic Management Journal, 19: 631-661.

Carmeli, A., \& Schaubroeck, J. 2005. How leveraging human resource capital with its competitive distinctiveness enhances the performance of commercial and public organizations. Human Resource Management, 44: 391-412.

Chadwick, C., Super, J. F., \& Kwon, K. 2015. Resource orchestration in practice: CEO emphasis on SHRM, commitment-based HR systems, and firm performance. Strategic Management Journal, 36: 360-376.

Chakravarthy, B., \& Lorange, P. 2007. Profit or growth? Why you don't have to choose. Englewood Cliffs, NJ: Wharton School.

Chang, Y. Y., Gong, Y., \& Peng, M. W. 2012. Expatriate knowledge transfer, subsidiary absorptive capacity, and subsidiary performance. Academy of Management Journal, 55: 927-948.

Chatman, J. 1991. Matching people and organizations: Selection and socialization in public accounting firms. Administrative Science Quarterly, 36: 459-484. 
Chatterjee, S. 1986. Types of synergy and economic value: The impact of acquisitions on merging and rival firms. Strategic Management Journal, 7: 119-139.

Chatterjee, S., \& Brueller, N. N. 2015. A new M\&A methodology: Five lessons in anticipating post-merger resource interactions and challenges. Strategy \& Leadership, 43(4): 26-37.

Chatterjee, S., \& Lubatkin, M. 1990. Corporate mergers, stockholder diversification and changes in systematic risk. Strategic Management Journal, 11: 255-268.

Christensen, C. M., Alton, R., Rising, C., \& Waldeck, A. 2011. The big idea: The new M\&A playbook. Harvard Business Review, 89(3): 48-57.

Chuang, C.-H., Jackson, S. E., \& Jiang, Y. in press. Can knowledge-intensive teamwork be managed? Examining the roles of HRM systems and leadership. Journal of Management. doi:10.1177/0149206313478189

Chuang, C., \& Liao, H. 2010. Strategic human resource management in service context: Taking care of business by taking care of employees and customers. Personal Psychology, 63: 153-196.

Citera, M., \& Rentsch, J. 1993. Is there justice in organizational acquisitions? The role of distributive and procedural fairness in corporate acquisitions. In R. Cropanzano (Ed.), Justice in the workplace: Approaching fairness in human resource management: 211-230. Hillsdale, NJ: Erlbaum.

Claus, L. 2006. Strategic global HR at Teva Pharmaceuticals. Thunderbird International Business Review, 48: 891-905.

Coffman, C. W., \& Sorensen, K. 2013. Culture eats strategy for lunch. Denver: Liang Addison Press.

Collins, C. J., \& Smith, K. G. 2006. Knowledge exchange and combination: The role of human resource practices in the performance of high-technology firms. Academy of Management Journal, 49: 544-560.

Combs, J., Liu, Y., Hall, A., \& Ketchen, D. 2006. How much do high-performance work practices matter? A metaanalysis of their effects on organizational performance. Personnel Psychology, 59: 501-528.

Cording, M., Christman, P., \& King, D. 2008. Reducing causal ambiguity in acquisition integration: Intermediate goals as mediators of integration decisions and acquisition performance. Academy of Management Journal, 51: 744-767.

Datta, D. K., Pinches, G. E., \& Narayanan, V. K. 1992. Factors influencing wealth creation from mergers and acquisitions: A meta-analysis. Strategic Management Journal, 13: 67-84.

Delaney, J. T., \& Huselid, M. A. 1996. The impact of human resource management practices on perceptions of organizational performance. Academy of Management Journal, 39: 949-969.

Delery, J. E., \& Shaw, J. D. 2001. The strategic management of people in work organizations: Review, synthesis, and extension. In G. R. Ferris (Ed.), Research in personnel and human resource management, vol. 20: 167-197. Stamford, CT: JAI Press.

Dhanaraj, C., Lyles, M. A., Steensma, H. K., \& Tihanyi, L. 2004. Managing tacit and explicit knowledge transfer in IJVs: The role of relational embeddedness and the impact on performance. Journal of International Business Studies, 35: 428-442.

Dierickx, I., \& Cool, K. 1989. Asset stock accumulation and sustainability of competitive advantage. Management Science, 35: 1504-1511.

Eisenhardt, K. M., Furr, N. R., \& Bingham, C. B. 2010. Microfoundations of performance: Balancing efficiency and flexibility in dynamic environments. Organization Science, 21: 1263-1273.

Eisenhardt, K. M., \& Martin, J. A. 2000. Dynamic capabilities: What are they? Strategic Management Journal, 21 : 1105-1121.

Ellis, K. 2004. Managing the acquisition process: Do differences actually exist across integration approaches. In A. Pablo \& M. Javidan (Eds.), Mergers and acquisitions: Creating integrative knowledge: 113-134. Oxford, England: Blackwell.

Finkelstein, S. 2003. Why smart executives fail, and what you can learn from their mistakes. New York: Portfolio.

Fiss, P. C. 2007. A set-theoretic approach to organizational configurations. Academy of Management Review, 32: 1180-1198.

Galpin, T. J., \& Herndon, M. 2014. The complete guide to mergers \& acquisitions: Process tools and templates for merger integration at every level (3rd ed.). San Francisco: Jossey-Bass.

Gant, J., Ichniowski, C., \& Shaw, K. 2002. Social capital and organizational change in high-involvement and traditional work organizations. Journal of Economics and Management Strategy, 11: 289-328.

Gardner, T. M., Wright, P. M., \& Moynihan, L. M. 2011. The impact of motivation, empowerment, and skillenhancing practices on aggregate voluntary turnover: The mediating effect of collective affective commitment. Personnel Psychology, 64: 315-350. 
Gelade, G. A., \& Ivery, M. 2003. The impact of human resource management and work climate on organizational performance. Personnel Psychology, 56: 383-404.

Gerhart, B. 2007. Horizontal and vertical fit in human resource systems. In C. Ostroff \& T. A. Judge (Eds.), Perspectives on organizational fit: 317-348. New York: Psychology Press.

Gittell, J. H., Seidner, R., \& Wimbush, J. 2010. A relational model of how high-performance work systems work. Organization Science, 21: 490-506.

Gong, Y., Law, K. S., Ghang, S., \& Xin, K. R. 2009. Human resources management and firm performance: The differential role of managerial affective and continuance commitment. Journal of Applied Psychology, 94: 263-275.

Granstrand, O., \& Sjölander, S. 1990. The acquisition of technology and small firms by large firms. Journal of Economic Behavior and Organization, 13: 367-386.

Guest, D. E. 1997. Human resource management and performance: A review and research agenda. The International Journal of Human Resource Management, 8: 263-276.

Guthrie, J. P. 2001. High-involvement work practices, turnover, and productivity: Evidence from New Zealand. Academy of Management Journal, 44: 180-190.

Haleblian, J., Devers, C. E., McNamara, G., Carpenter, M. A., \& Davison, R. B. 2009. Taking stock of what we know about mergers and acquisitions: A review and research agenda. Journal of Management, 35: 469-502.

Haspeslagh, P., \& Jemison, D. 1991. Managing acquisitions. New York: Free Press.

Hempel, P. S., Zhang, Z., \& Han, Y. 2012. Team empowerment and the organizational context: Decentralization and the contrasting effects of formalization. Journal of Management, 38: 475-501.

Hitt, M., Harrison, J., Ireland, D., \& Best, A. 1998. Attributes of successful and unsuccessful acquisitions of US firms. British Journal of Management, 9: 91-114.

Horovitz, J. 2004. Some key pitfalls in acquisitions. In P. Morosini \& U. Steger (Eds.), Managing complex mergers: Real world lessons in implementing successful cross-cultural mergers and acquisitions: 116-134. London: Prentice Hall.

Hubbard, N., \& Purcell, J. 2001. Managing employee expectations during acquisitions. Human Resource Management Journal, 11: 17-34.

Huber, G. P. 1991. Organizational learning: The contributing processes and the literatures. Organization Science, 2: $88-115$.

Huselid, M. A. 1995. The impact of human resource management practices on turnover, productivity, and corporate financial performance. Academy of Management Journal, 38: 635-672.

Ichniowski, C., Shaw, K., \& Prennushi, G. 1997. The effects of human resource management practices on productivity: A study of steel finishing lines. American Economic Review, 87: 291-313.

Jackson, S. E., Schuler, R. S., \& Jiang, K. 2014. An aspirational framework for strategic human resource management. Academy of Management Annals, 8: 1-56.

Jiang, K., Lepak, D. P., Hu, J., \& Baer, J. C. 2012. How does human resource management influence organizational outcomes? A meta-analytic investigation of mediating mechanisms. Academy of Management Journal, 55: 1264-1294.

Jiang, K., Takeuchi, R., \& Lepak, D. P. 2013. Where do we go from here? New perspectives on the black box in strategic human resource management research. Journal of Management Studies, 50: 1448-1480.

Jonsson, A., \& Foss, N. J. 2011. International expansion through flexible replication: Learning from the internationalization experience of IKEA. Journal of International Business Studies, 42: 1079-1102.

Kanter, R. M. 2009. Mergers that stick. Harvard Business Review, 87(10): 121-125.

Karim, S., \& Mitchell, W. 2000. Path-dependent and path-breaking change: Reconfiguring business resources following acquisitions in the U.S. medical sector, 1978-1995. Strategic Management Journal, 21: 1061-1081.

Katou, A. A., \& Budhwar, P. S. 2006. Human resource management systems and organizational performance: A test of a mediating model in the Greek manufacturing context. The International Journal of Human Resource Management, 17: 1223-1253.

Katz, H. G., Kochan, T. A., \& Weber, M. A. 1985. Assessing the effects of industrial relations systems and efforts to improve the quality of working life on organizational effectiveness. Academy of Management Journal, 28: 509-526.

Kehoe, R. R., \& Wright, P. M. 2013. The impact of high performance human resource practices on employees' attitudes and behaviors. Journal of Management, 39: 366-391.

King, D. R., Dalton, D. R., Daily, C. M., \& Covin, J. G. 2004. Meta-analyses of post-acquisition performance: Indications of unidentified moderators. Strategic Management Journal, 25: 187-200. 
King, D. R., Slotegraaf, R. J., \& Kesner, I. 2008. Performance implications of firm resource interactions in the acquisition of R\&D-intensive firms. Organization Science, 19: 327-340.

Koller, T., Goedhart, M., \& Wessels, D. 2010. Valuation (5th ed.). New York: Wiley Finance.

Larsson, R., \& Finkelstein, S. 1999. Integrating strategic, organizational, and human resource perspectives on mergers and acquisitions: A case survey of synergy realization. Organization Science, 10: 1-26.

Larsson, R., \& Lubatkin, M. 2001. Achieving acculturation in mergers and acquisitions: An international case survey. Human Relations, 54: 1573-1607.

Leonard-Barton, D. A. 1995. Wellsprings of knowledge: Building and sustaining the sources of innovation. Boston: Harvard Business School Press.

Lepak, D. P., Liao, H., Chung, Y., \& Harden, E. E. 2006. A conceptual review of human resource management systems in strategic human resource management research. In J. J. Martocchio (Ed.), Research in personnel and human resource management, vol. 25: 217-271. Greenwich, CT: JAI Press.

Lepak, D. P., \& Snell, S. A. 2002. Examining the human resource architecture: The relationships among human capital, employment, and human resource configurations. Journal of Management, 28: 517-543.

Liao, H., Toya, K., Lepak, D. P., \& Hong, Y. 2009. Do they see eye to eye? Management and employee perspectives of high-performance work systems and influence processes on service quality. Journal of Applied Psychology, 94: $371-391$.

Lubatkin, M. H. 1983. Mergers and the performance of the acquiring firm. Academy of Management Review, 8: 218-225.

Lubatkin, M. H. 1987. Merger strategies and stockholder value. Strategic Management Journal, 8: 39-53.

Mahoney, J. T., \& Kor, Y. Y. 2015. Advancing the human capital perspective on value creation by joining capabilities and governance approaches. Academy of Management Perspectives, 29(3): 296-308.

Markman, G. D., \& Waldron, T. L. 2014. Small entrants and large incumbents: A framework of micro entry. Academy of Management Perspectives, 28(2): 179-197.

Marks, M. 1997. Consulting in M\&As: Interventions spawned by recent trends. Journal of Organizational Change, 10: 267-279.

Marks, M. L., \& Mirvis, P. H. 1998. Joining forces: Making one plus one equal three in mergers, acquisitions and alliances. San Francisco: Jossey-Bass.

Mayer, D., \& Kenney, M. 2004. Economic action does not take place in a vacuum: Understanding Cisco's acquisition and development strategy. Industry and Innovation, 11: 299-325.

McClean, E., \& Collins, C. J. 2011. High-commitment HR practices, employee effort, and firm performance: Investigating the effects of HR practices across employee groups within professional services firms. Human Resource Management, 50, 341-363.

Miller, F. D., \& Fernandes, E. 2009. Cultural issues in mergers and acquisitions. http://www2.deloitte.com/content/dam/Deloitte/us/Documents/mergers-acqisitions/us-ma-consulting-cultural-issues-in-ma-010710.pdf. Accessed December 22, 2015.

Nahavandi, A., \& Malekzadeh, A. R. 1988. Acculturation in mergers and acquisitions. Academy of Management Review, 13: 79-90.

Nyberg, A. J., Moliterno, T. P., Hale, D., \& Lepak, D. 2014. Resource-based perspectives on unit-level human capital: A review and integration. Journal of Management, 40: 316-346.

Nyberg, A. J., \& Wright, P. M. 2015. 50 years of human capital research: Assessing what we know; exploring where we go. Academy of Management Perspectives, 29(3): 287-295.

Pablo, A. L. 1994. Determinants of acquisition integration level: A decision-making perspective. Academy of Management Journal, 37: 803-836.

Paulson, E. 2001. Inside Cisco: The real story of sustained M\&A growth. New York: John Wiley \& Sons.

Pierce, J. R., \& Aguinis, H. 2013. The too-much-of-a-good-thing effect in management. Journal of Management, 39: 313-338.

Ployhart, R. E., Nyberg, A. J., Reilly, G., \& Maltarich, M. A. 2014. Human capital is dead; long live human capital resources! Journal of Management, 40: 371-398.

Ployhart, R. E., Weekley, J. A., \& Baughman, K. 2006. The structure and function of human capital emergence: A multilevel examination of the attraction-selection-attrition model. Academy of Management Journal, 49: 661-677.

Porter, M. E. 1987. From competitive advantage to corporate strategy. Harvard Business Review, 65(3): 43-59. 
Puranam, P. 2001. Grafting innovation: The acquisition of entrepreneurial firms by established firms. Unpublished doctoral dissertation, University of Pennsylvania, Philadelphia.

Puranam, P., Singh, H., \& Chaudhuri, S. 2009. Integrating acquired capabilities: When structural integration is (un)necessary. Organization Science, 20: 313-328.

Puranam, P., \& Srikanth, K. 2007. What they know vs. what they do: How acquirers leverage technology acquisitions. Strategic Management Journal, 28: 805-825.

Ranft, A. L., \& Lord, M. D. 2000. Acquiring new knowledge: The role of retaining human capital in acquisitions of high-tech firms. Journal of High Technology Management Research, 11: 295-319.

Ryan, R. M., \& Deci, E. L. 2000. Self-determination theory and the facilitation of intrinsic motivation, social development, and well-being. American Psychologist, 55: 68-78.

Schneider, B. 1987. The people make the place. Personnel Psychology, 40: 437-453.

Schuler, R. S., \& Jackson, S. E. 2003. Seeking an edge in mergers and acquisitions. In J. Pickford (Ed.), Mastering people management: 47-52. London: Pearson Education.

Schweiger, D. M. 2002. M\&A integration: A framework for executives and managers. New York: McGraw Hill.

Seth, A. 1990. Sources of value creation in acquisitions: An empirical investigation. Strategic Management Journal, 11: 431-446.

Shi, W., Sun, J., \& Prescott, J. E. 2012. A temporal perspective of merger and acquisition and strategic alliance initiatives: Review and future direction. Journal of Management, 38: 164-209.

Siegel, D. S., \& Simons, K. L. 2007. Assessing the effects of mergers and acquisitions on firm performance, plant productivity, and workers: New evidence from matched employer-employee data. Strategic Management Journal, 31: 903-916.

Smith, L. G. E., Amiot, C. E., Smith, J. R., Callan, V. J., \& Terry, D. J. 2013. The social validation and coping model of organizational identity development: A longitudinal test. Journal of Management, 39: 1952-1978.

Stahl, G. K., \& Voigt, A. 2008. Do cultural differences matter in mergers and acquisitions? A tentative model and examination. Organization Science, 19: 160-176.

Subramony, M. 2009. A meta-analytic investigation of the relationship between HRM bundles and firm performance. Human Resource Management, 48: 745-768.

Sun, L., Aryee, S., \& Law, K. 2007. High-performance human resource practices, citizenship behavior and organizational performance: A relational perspective. Academy of Management Journal, 50: 558-577.

Swaminathan, V., Groening, C., Mittal, V., \& Thomaz, F. 2014. How achieving the dual goal of customer satisfaction and efficiency in mergers affects a firm's long-term financial performance. Journal of Service Research, 17: 182-194.

Szulanski, G. 1996. Exploring internal stickiness: Impediments to the transfer of best practice within the firm. Strategic Management Journal, 17: 27-43.

Takeuchi, R., Lepak, D. P., Wang, H., \& Takeuchi, K. 2007. An empirical examination of the mechanisms mediating between high-performance work systems and the performance of Japanese organizations. Journal of Applied Psychology, 92: 1069-1083.

Tarba, S. Y., Almor, T., \& Benjamini, H. 2012. A comparative anatomy of two cross-border acquisitions by Teva Pharmaceutical Industries. In C. L. Cooper \& S. Finkelstein (Eds.), Advances in mergers and acquisitions, vol. 10: 75-102. Bingley, England: Emerald Group.

Teece, D. J., Pisano, G., \& Shuen, A. 1997. Dynamic capabilities and strategic management. Strategic Management Journal, 18: 509-533.

Tharenou, P., Saks, A., \& Moore, C. 2007. A review and critique of research on training and organizational-level outcomes. Human Resource Management Review, 17: 251-273.

Tsui, A. S., Pearce, J. L., Porter, L. W., \& Tripoli, A. M. 1997. Alternative approaches to the employee-organization relationship: Does investment in employees pay off? Academy of Management Journal, 40: 1089-1121.

Tyler, T. R., Boeckmann, R. J., Smith, H. J., \& Huo, Y. 1997. Social justice in a diverse society. Denver: Westview Press.

Uyterhoeven, H. 1996. Banc One-1993. Harvard Business School case 9-394-043, Boston.

Vaara, E., Sarala, R., Stahl, G. K., \& Björkman, I. 2012. The impact of organizational and national cultural differences on social conflict and knowledge transfer in international acquisitions. Journal of Management Studies, 49: 1-27.

Viegas-Pires, M. 2013. Multiple levels of culture and post M\&A integration: A suggested theoretical framework. Thunderbird International Business Review, 55: 357-370. 
Vigodman, E. 2015. Teva sends letter to Mylan board. http://www.tevapharm.com/news/?itemid=\%7B88426416D88C-4CD3-9928-7A0B8145FDB2\%7D. Accessed July 12, 2015.

Vogus, T. J. 2006. What is it about relationships? A behavioral theory of social capital and performance. In A. Eaton (Ed.), Proceedings of the 58th annual meeting of the Labor and Employment Relations Association, vol. 58: 164-173. Champaign, IL: Labor and Employment Relations Association.

Wagner, J. A., III. 1994. Participation's effects on performance and satisfaction: A reconsideration of research evidence. Academy of Management Review, 19: 312-330.

Wang, H. C., He, J., \& Mahoney, J. T. 2009. Firm-specific knowledge resources and competitive advantage: The roles of economic- and relationship-based employee governance mechanisms. Strategic Management Journal, 30: $1265-1285$.

Way, S. A., Fay, C. H., Wright, P. M., Snell, S. A., Chang, S., \& Gong, Y. 2015. Validation of a multidimensional HR flexibility measure. Journal of Management, 41: 1098-1131.

Weber, R. A., \& Camerer, C. F. 2003. Cultural conflict and merger failure: An experimental approach. Management Science, 49: 400-415.

Wright, P. M., \& Boswell, W. R. 2002. Desegregating HRM: A review and synthesis of micro and macro human resource management research. Journal of Management, 28: 247-276.

Wright, P. M., Coff, R., \& Moliterno, T. P. 2014. Strategic human capital crossing the great divide. Journal of Management, 40: 353-370.

Wright, P. M., Dunford, B. B., \& Snell, S. A. 2001. Human resources and the resource based view of the firm. Journal of Management, 27: 701-721.

Wright, P. M., Gardner, T. M., Moynihan, L. M., \& Allen, M. R. 2005. The relationship between HR practices and firm performance: Examining causal order. Personnel Psychology, 58: 409-446.

Yang, G., \& Lin, G. Y. 2009. Does intellectual capital mediate the relationship between HRM and organizational performance? Perspective of a healthcare industry in Taiwan. The International Journal of Human Resource Management, 20: 1965-1984.

Yirrell, S. 2007. Cisco reassures IronPort VARs. CRN, January 11. http://www.channelweb.co.uk/crn-uk/ news/1876629/cisco-reassures-ironport-vars. Accessed December 22, 2015.

Youndt, M. A., \& Snell, S. A. 2004. Human resource configurations, intellectual capital, and organizational performance. Journal of Managerial Issues, 16: 337-360.

Zollo, M., \& Singh, H. 2004. Deliberate learning in corporate acquisitions: Post-acquisition strategies and integration capability in U.S. bank mergers. Strategic Management Journal, 25: 1233-1256.

Zott, C., Amit, R., \& Massa, L. 2011. The business model: Recent developments and future research. Journal of Management, 37: 1019-1042. 